Please do not remove this page

RMIT

UNIVERSITY

\title{
Employment regulation and worker-carers: reproducing gender inequality in the domestic and market spheres?
}

Charlesworth, Sara; Macdonald, Fiona

https://researchrepository.rmit.edu.au/esploro/outputs/9921858750401341/filesAndLinks?institution=61RMIT_INST\&index=null

Charlesworth, S., \& Macdonald, F. (2017). Employment regulation and worker-carers: reproducing gender inequality in the domestic and market spheres? In Women, Labor Segmentation and Regulation: Varieties of Gender Gaps (pp. 79-96). Palgrave Macmillan. https://doi.org/10.1057/978-1-137-55495-6_5

Document Version: Accepted Manuscript

Published Version: https://doi.org/10.1057/978-1-137-55495-6_5

Repository homepage: https://researchrepository.rmit.edu.au

(c) The Author(s) 2017

Downloaded On 2023/04/26 21:35:28 +1000

Please do not remove this page 
Thank you for downloading this document from the RMIT Research Repository.

The RMIT Research Repository is an open access database showcasing the research outputs of RMIT University researchers.

RMIT Research Repository: http://researchbank.rmit.edu.au/

\section{Citation:}

Charlesworth, S and Macdonald, F 2017, 'Employment regulation and worker-carers: reproducing gender inequality in the domestic and market spheres?' in D. Peetz and G. Murray (ed.) Women, Labor Segmentation and Regulation: Varieties of Gender Gaps, Palgrave Macmillan, New York, United States, pp. 79-96.

See this record in the RMIT Research Repository at:

https://researchbank.rmit.edu.au/view/rmit:42884

Version: Accepted Manuscript

Copyright Statement:

(C) The Author(s) 2017

\section{Link to Published Version:}

http://dx.doi.org/10.1057/978-1-137-55495-6_5 


\title{
Employment regulation and worker-carers: Reproducing gender inequality in the domestic and market spheres?
}

\author{
Sara Charlesworth and Fiona Macdonald
}

\section{Introduction}

In this chapter we examine the ways in which the interaction of the domestic and market spheres shape and is shaped by gender inequality in both spheres, particularly for worker-carers-people who combine (unpaid) care work with paid work. We draw on critical feminist framings of the public-private divide and what this divide means for gender equality in employment. In particular our concern is with the reproduction of gender gaps in paid work, which have consequences for women across the life course. We consider the nature of the work-care regime, the gender norms that underpin it and the role of employment regulation in determining gender relations and the organisation and valuing of work and in perpetuating the reliance of employers on women's unpaid work in the domestic sphere to produce and support workers for the market.

This chapter focuses on the Australian case and examines the ways in which state interventions have attempted to mitigate some consequences of the interaction of the domestic and market spheres through various 'accommodations' of worker-carers. We argue that, for the most part, such accommodations have worked to both 'adapt' worker-carers to the demands of substantially unchanged workplaces and institutions and to reinforce the gendered division of labour in the workplace and the home. Finally we examine the ways in which the perception of paid care work as ‘women's work' — historically unpaid—has informed the profound undervaluing of this work as 
'work'. Focusing on the case of paid care work, particularly the frontline work undertaken by so-called 'low-skilled' women workers, allows us to draw attention to the implications of being in a female-dominated occupation. It also contributes to understanding how the interaction of the domestic and market spheres shapes outcomes for differently situated groups of women, in this case the low paid.

While this chapter is chiefly concerned with the role of employment regulation, we acknowledge there are broader contexts that shape the working conditions of worker-carers. These contexts are reflected in social and economic institutions and in employment practices at the workplace level. Our analysis draws on a substantive framing of gender equality that is about a transformation of gender relations towards an equal distribution of paid and unpaid work, equal pay and desegregation ${ }^{1}$. Thus our understandings of 'regulation distance' and regulation go beyond proximity and content of the regulation that sets employment conditions for worker-carers to include the ways in which regulation works to reduce or reinforce demarcations between the domestic and market spheres.

In this chapter we draw on an Australian case study to show how, across the labour market, even where regulation proximity is high, employment regulation fails to support worker-carers in ways that facilitate sharing of care between men and women. This failure of regulation is implicated in the gendered segmentation of the labour market, contributing to women's overrepresentation in sectors which appear to have high regulation proximity but where women are concentrated in less wellregulated part-time and casual jobs.

\section{Contexts}


In this section we outline the theoretical framings we employ and the current situation in Australia in respect to the resilient gendered divisions of labour in the market and domestic spheres.

\section{$2.1 \quad$ Theoretical framings}

Feminist debates around the public/private divide have theorised the main structures that reproduce gender inequality, in particular the organization of both labour and care ${ }^{2}$. The divisions between paid and unpaid work, or between the market and domestic spheres, are structures of power and are mutually dependent:

In this division of work, care is not seen as a collective responsibility of men and women, or of the whole of society, but as an individual responsibility of women. ${ }^{3}$

It is important here to be clear what we mean by gender (in)equality. Different framings of gender (in)equality shape the solutions seen as best for mitigating the gendered impact of the public/private divide, particularly as this relates to workercarers. ${ }^{4}$ Framing the problem of gender equality as sameness means that the issue becomes one of ensuring women have access to the same rights and opportunities as men in the market sphere. ${ }^{5}$ This view of equality has little to say about the division of labour in the domestic sphere. Framing equality as difference focuses instead on the male norm that dominates in the public sphere with strategies directed towards the accommodation of women's difference, including in respect to their care responsibilities. Seeing equality as the recognition of difference can run the risk of essentialising women as carers ${ }^{6}$ and indeed of positioning the problem of gender inequality solely as one of work/family conflict. The transformative framing of gender equality in contrast requires policy approaches designed to fundamentally 
transform the ways that domestic work and work in the market sphere are understood and undertaken. ${ }^{7}$

Gender (in)equality is reproduced in both the domestic and market spheres within the context of a specific societal 'gender contract' or 'gender order'. Connell's concept ${ }^{8}$ of the gender order of a society comprises production relations, power, emotional relations (including sexuality) and symbolic relations. These systems of social relations combine to determine the degree of gender inequality in a society. One critical element of the gender order that goes to the relations of production is what has been called the 'work-care regime'. ${ }^{9}$ This concept is useful for differentiating the combinations of institutional arrangements and social and cultural norms around men and women's work and care roles. The work-care regime defines the gender relations of production and the ways in which the domestic and market spheres interact and reinforce each other in any particular national context.

As a key institution of the work-care regime, employment regulation, along with social policy, acts to demarcate and gender the domestic and market spheres and reproduce gender (in)equalities in a variety of ways. Gottfried has aptly described how gender is inscribed in the subjects of labour regulation both 'reflect(ing) and affect(ing) power resources in the bargaining relationships within and across workplaces, between work and family, and in family life'. ${ }^{110}$ Thus, the doing and organizing of gender relations is in part a consequence of labour regulation. Similarly, understandings of labour law as constitutive ${ }^{11}$ underpins recent feminist legal perspectives in which employment regulation is seen as, not only reflecting and reinforcing gender norms, but as having normative and discursive dimensions and as having a role in defining and determining gender norms. ${ }^{12}$ 
Nowhere is the role of employment regulation in defining gender norms more apparent than in the construction of the Standard Employment Relationship (SER) ${ }^{13}$ as the standard around which labour protections pivot. The SER is a central element of the traditional 'male-breadwinner, female care-giver' model or regime. ${ }^{14}$ In this type of work-care regime, access to good quality jobs with career paths and regulatory protection and benefits is largely confined to men who can perform these mainly fulltime, full-year jobs because they are unencumbered by care responsibilities. As a consequence, while men's full-time labour force participation is made possible by women's unpaid care-giving, the majority of women are excluded entirely from paid work or confined to 'non-standard' insecure and lower-paid jobs with fewer benefits. $^{15}$

With changing social arrangements and the large-scale entry of womenincluding women with dependent children-into the paid workforce the gender order underpinning this particular work-care regime has partially broken down, to different degrees and in different ways, in most developed countries. While these changes have 'revealed the extent to which employment norms rested on an unpaid, full-time caregiver ${ }^{16}$, they have not led to the establishment of new norms for labour and care work based on a transformative vision of gender equality, such as the universal carer/worker-worker/carer model ${ }^{17}$ that would transform gender relations. As we outline later in this chapter, in Australia the basic scaffolding of contemporary employment regulation leaves much part-time work poorly protected and with fewer benefits while there has been little progress towards a 'flexible SER'18, continuing women's economic dependence on a male partner and consequent vulnerability.

How employment regulation addresses the domestic and market divide and the ways in which worker-carers attempt to balance responsibilities across both the 
market and domestic spheres continues to be shaped by social norms. For example, in Australia the extent to which mothers engage in paid work is profoundly influenced by dominant gender norms that only support women's greater engagement in paid work on condition that work does not interfere with their 'primary' responsibilities as mothers nor alter gendered divisions of labour in the household. ${ }^{19}$ Such social norms not only underpin the large-scale take up of part-time work by Australian women, but as we highlight below, also shape the distinctive and gendered polarization of work hours.

\subsection{The household division of labour}

International comparative research suggests that, within a national work-care regime, state interventions around work and care shape the ways in which men and women negotiate unpaid labour in the home and the basis on which they engage in paid work. ${ }^{20}$ Available data show that, despite women’s increasing participation in paid work, strong gender divisions and inequalities remain in both domestic and market spheres. Across developed countries, women continue to spend far more time in unpaid work than men, with the OECD average being 4.6 hours per day for women and 2.4 hours per day for men. ${ }^{21}$ In Australia, the gender divide in unpaid work is similar. In 2006, women spent 5.2 hours per day in unpaid work compared to 2.9 hours for men. This divide in unpaid work had remained substantially unchanged from 1997. While men did not increase their time spent on household activities over the decade, they did increase their time spent in childcare within the family. However so did women, who, in 2006, spent almost three times as long on childcare activities than men. ${ }^{22}$ Caregiving for older dependents is also gendered, with one study finding women aged 35-64 years were much more engaged than men in caring for adult relatives. $^{23}$ 
In families without dependent children there has been some reduction over time in 'gender specialization' in the market and domestic spheres. ${ }^{24}$ However there remains a sharp divide between the time spent in paid work by women and men when they become parents. In particular the presence of children appears to decrease mothers' hours in paid work and increase fathers' hours in paid work. In Australia in 2013-14, amongst parents with a youngest child under 5 years, 94 per cent of fathers were in the labour force compared to just 60 per cent of mothers. ${ }^{25}$ Indeed fathers, whether partnered or sole parents, reported the longest work hours of all male and female workers. ${ }^{26}$ While sole mothers worked similar hours to partnered mothers ${ }^{27}$, a clear, gendered distribution of work hours was apparent for couple families, with mothers working part-time hours and father working full-time hours. This pattern reflects the growing importance of the 'one and a half earner' model across the $\mathrm{OECD}^{28}$. What is distinctive about the Australian context, however, is the extent of working time polarization for parents with young children, with mothers clustered in relatively short-hours, mainly casual, part-time jobs and fathers in long-hours, fulltime jobs. $^{29}$

This gendered polarisation works to undermine mothers’ access to good quality jobs, with negative consequences both in the short and longer term. It thus has profound consequences for gender equality over the life course, relegating many women who get stuck in part-time jobs to poorer career outcomes and lower incomes in retirement. In the domestic sphere the gendered polarisation of work hours reinforces gender inequality by making it harder for fathers to engage in parenting and other unpaid domestic work. ${ }^{30}$ More generally, both gender norms and the relatively high share of female part-time employment in Australia shape the ways in which men and women negotiate and organize within the domestic sphere. ${ }^{31}$ 
The consequences for women of this maladaption of the market sphere to the needs of worker-carers is reflected in the significantly higher levels of work-life interference experienced by women. ${ }^{32}$ Of particular interest is that regardless of total hours worked — whether part-time (1-34 hours), full time (35-47 hours), or long full time (48 hours+)—women experience worse work-life interference than men. ${ }^{33}$ This suggests that part-time work does not remove work-life pressures. For example mothers who engage in paid work tend to preserve time for childcare by reducing time spent on personal care and leisure. ${ }^{34}$

In Australia, as we explore below, employment regulation maps on to the gendered polarization of full-time and non-standard work, underpinning the poorer quality work available to those who work non-standard part-time hours or in casual employment. This constrains the effectiveness of regulatory interventions that might support worker-carers.

\section{Regulatory Interventions}

In this section we provide an overview of Australian state-level regulation that has been used to help workers bridge the divide between the market and domestic spheres. Labour law, with other employment regulation, is a key state 'intervention' assumed to help workers reconcile paid work and unpaid domestic and caring responsibilities. We ask how effective this regulation has been in addressing the needs of worker-carers and in addressing gender gaps stemming from the divide between the market and domestic spheres. These interventions take place within a broader national context and they interact with other interventions at the macro social and economic levels and at the workplace level. ${ }^{35}$ Thus we also focus briefly on the implementation of a key Australian social policy - the national paid parental leave 
scheme, which interacts with employment regulation, and is designed to provide some support for new parent worker-carers.

\subsection{Employment regulation}

Unlike many other countries, in Australia the recognition in employment regulation that the market and domestic spheres are at least partially intertwined has long historical roots. In 1907 the Harvester decision of the federal industrial court, provided for a living or family wage sufficient to keep a man, his wife and three dependents in 'frugal comfort'. ${ }^{36}$ The Harvester decision was innovative in acknowledging that workers' responsibilities did not stop at the factory gate but flowed on to the domestic sphere. However it failed to recognize the extent to which the domestic sphere supported the market sphere of male work. Indeed the Harvester decision institutionalized the male breadwinner in Australian labour regulation. It also implicitly institutionalized the female homemaker, whom it was assumed would undertake the caring and domestic work necessary to allow the male breadwinner to provide for the family through paid work. ${ }^{37}$ Today the male-breadwinner model is still reflected in the normative divide in employment regulation between what is seen and valued as men's and women's work, and in the poorer wages and conditions that attach to the non-standard work outside the SER in which women are overrepresented. In particular, the working time conditions so crucial to the reconciliation of work and care are generally poorer in feminized industries than those in male-dominated industries

In cross-national comparison, Australian labour law was an 'early adopter' of regulatory interventions designed to recognize and support worker carers. The domestic sphere was formally acknowledged in a number of crucial 'test cases' from 1979 onwards. ${ }^{38}$ The first direct legal recognition of worker-carers was the 1979 
Maternity Leave Test Case, which ensured eligible women workers could return to their job after up to 12 months' unpaid leave. In 1990 another test case saw maternity leave broadened to parental leave (that is, fathers also become entitled to unpaid leave) and in 2001 a further test case decision extended unpaid parental leave to eligible casual employees. ${ }^{39}$ Further test cases—on paid 'family leave' in 1994 and then 'personal/carers' leave in 1996 — allowed an employee to access part of their sick leave entitlements when a family member was ill. In 2005, a test case decision of the industrial relations commission introduced a limited 'right to request' part-time work for employees after parental leave. The flow on of that decision into industry awards, however, was truncated by the 'WorkChoices' changes to federal labour law. ${ }^{40}$

Today Australian employment regulation provides a relatively comprehensive set of supports to worker carers. There is however a crucial statutory distinction between 'casual' employment and other forms of employment that limits the access of many low-paid women workers to regulatory supports. Casual work is has no job security, guarantee of hours or access to paid sickness or recreation leave. Part-time workers are more likely than their full-time counterparts to be employed on a casual basis. Women are much more likely than men to be in part-time work and more likely to be working on a casual basis than men. In 2013, 27 per cent of female employees were employed casually compared to 21 per cent of men, with casual work predominating in feminized industries such as retail. ${ }^{41}$ Casual employees have limited access to formal worker-carer provisions contained in statutory entitlements under the Fair Work Act 2009 as we note below. They also have less access to any working time predictability provided to non-casual employees in sectoral regulation known as Modern Awards. However casual status is not the only indicator of poor quality, parttime work. In many feminized industries those classified as part-time (rather than 
casual) do not necessarily have access to pro-rata full-time conditions. Indeed parttime provisions in many of these awards such as in the social care sector are much weaker in terms of working time security than comparable provisions in awards in male-dominated industries. ${ }^{42}$

Explicit employment regulation designed to accommodate worker-carers includes unpaid parental leave, personal/carers leave and a limited right to request flexible work arrangements make up three of the ten statutory National Employment Standards (NES) of the Fair Work Act. Access to these provisions is limited for many workers. Paid personal/carers leave is not available to casual workers although they may access up to two days unpaid leave. Parental leave and the right to request flexible work are only available to those who have had 12 months service with their employer and, if casual, are employed on a regular and systematic basis with the likelihood of ongoing employment.

Arguably parental leave, carers leave and the short-lived right to request parttime work won through test cases and reflected in the current NES all strongly reinforce a normative family and a mode of caring based on one adult being the main or sole carer for the baby rather than shared caring. ${ }^{43}$ Eligibility for the right to request flexible work is now broader than caring for a young child: in 2013 it was extended to include carers as well as workers with disabilities and workers who experience family violence. However this provision is weaker than similar provisions in the Netherlands, Germany and the United Kingdom, and remains constrained by the lack of effective appeal rights, service requirements and the ongoing and systematic employment requirement for casuals. ${ }^{44}$

One of the most innovative regulatory interventions has been provision for domestic violence leave negotiated in many enterprise agreements. This leave is 
designed to assist employees to remain in paid employment and support them through the process of escaping violence. ${ }^{45}$ Currently only accessible by full-time and parttime workers covered by such agreements, it typically enables paid leave to be taken in addition existing leave entitlements. The Australian Council of Trade Unions (ACTU) has made a claim as part of the 2014-2016 Modern Award Review for 10 days’ paid domestic violence leave (with 10 days’ unpaid leave for casual employees). ${ }^{46}$ While employer groups have been hostile to this claim ${ }^{47}$, the unlikely but sympathetic consideration of domestic violence leave by the conservative Productivity Commission in its Workplace Relations Framework inquiry report ${ }^{48}$ and greater societal awareness of the problem of domestic violence may well see its introduction into modern awards.

This would be a welcome breach in the sharp divide between the domestic and market spheres. The recognition that gender relations in the domestic sphere can become a workplace issue is particularly important, given that most regulation designed to support worker-carers is focused, at best, on accommodating worker's unpaid care responsibilities at work. However, unless paid domestic violence leave is available to all workers, it will offer little practical support to worker-carers on casual contracts, who remain much more dependent on the enforcement of their poorer working time rights under industry awards. ${ }^{49}$

\subsection{Paid Parental Leave.}

A range of macro-social and economic institutions also affect the ways in which worker-carers live and work. ${ }^{50}$ These include the provision of childcare and other social infrastructure as well as taxation and social security payments, including paid parental leave. A key social policy intervention was the 2011 introduction of a national government-funded paid parental leave (PPL) scheme. The ultimate 
implementation of PPL came after a long campaign by feminists and unionists that drew on the labour law provision for unpaid parental leave, two inquiries by the Australian Human Rights Commission (in1998 and 2005) and slowly growing Labor party support. ${ }^{51}$

PPL provides 18 weeks paid leave at the rate of the national minimum wage (NMW). It has relatively generous eligibility criteria compared to those for unpaid parental leave. The primary carer can be a permanent employee, casual worker, contractor, or self-employed and must have worked at least 330 hours in 10 of the previous 13 months. In 2013, an extension to the scheme designed to encourage fathers and partners to take a greater share of caring responsibilities-Dad and Partner Pay (DaPP)—became available to the partner of the primary carer on a 'use it or lose it basis' for a period of 2 weeks, also at the NMW. ${ }^{52}$ While currently politically contested (at the time of writing the conservative Coalition government was proposing to limit access to those without employer-funded parental leave), PPL is generally seen as a practical albeit limited intervention to meet the original policy objectives. These included enhancing infant and maternal well-being by assisting mothers to stay home from work with their babies, increasing female workforce participation and improving gender equity by recognizing the caring and nurturing roles of parents. ${ }^{53}$

A comprehensive evaluation of the operation of the PPL scheme, undertaken in 2014, found that till then PPL had had no impact on the division of childcare or housework tasks between mothers and their partners. ${ }^{54}$ There was little difference following the introduction of PPL in the extent of support during pregnancy or in the use of workplace flexibility arrangements on return to work. ${ }^{55}$ The introduction of PPL was associated with an improvement in mothers' views about their post-birth 
career prospects; though almost a third of mothers who had accessed PPL still reported that their career prospects when they returned to work were worse than before the birth of their baby. ${ }^{56}$

This suggests that while PPL has reduced the financial barriers to parents taking leave following a birth and has encouraged mothers to return to work by the time their babies are 12 months old, it has had little impact on the gender inequality straddling the market and domestic spheres. As the evaluation authors note, these findings point both to the resilience of norms about gender roles and of workplace cultures that set the climate for the support of working mothers. ${ }^{57}$ However while the take-up of DaPP remained low (just over one third of eligible fathers took DaPP), there was some evidence that it opened up 'a space to consider new expectations about men's role as fathers and how their roles as fathers fit with their work' ${ }^{58}$

\section{Social care work}

The case of social care work provides another illustration of the role employment regulation plays in shaping the interaction of the domestic and market spheres. How paid social care work—including caring for the elderly, for children and for people with disability—is valued also has particular importance to the achievement of gender equality goals. The social devaluing of paid care work reflects not only its being overwhelmingly undertaken by women but also its direct connection to the unpaid work women traditionally performed in the home and community. ${ }^{59}$ For the realization of gender equality based on a 'shared work - valued care' model—whereby women have equal access to good jobs and unpaid caring is valued and shared between women and men—paid care jobs must be decent jobs. ${ }^{60}$ 
In many OECD countries social care work is not only highly feminized but racialized, often performed by migrant women without citizenship status who are reliant on others to care for family members who have not migrated with them. ${ }^{61}$ While paid care workers of both sexes continue to be economically disadvantaged in many countries, the wage penalties are mostly much more severe for women ${ }^{62}$ and there remain strong divisions between the type of social care work undertaken by men and women.

Employment regulation reinforces the gendered social undervaluation of paid care work and reproduces it as low paid and low status work. For example, in Australia, the Social Community Home Care and Disability Services Award 2010 sets down minimum pay and working conditions that are meager in comparison with those provided under the industrial awards for other occupations, and this applies for ongoing as well as for casual workers. ${ }^{63}$ The absence of any detail of skill requirements in the classifications on which the wages are based is striking, particularly in the lower-paid care work classifications. While an historic industrywide community services equal pay case in 2012, conducted under the Fair Work Act, awarded significant increases for many classifications, the equal pay decision was ambivalent about recognizing the extent of gendered undervaluation of care work. ${ }^{64}$ In this regard the decision failed to reflect recognition in an earlier equal pay decision by a state-level tribunal—the Queensland Industrial Relations Commission (QIRC) (2009) — that underlying undervaluation is that 'the nature of care work is considered to be an extension of women's work in the home, an inherent part of mothering, ${ }^{65}$ and that this undervaluation permeates funding arrangements and the structures and processes of employment regulation. 
Internationally, while aspirations for decent work for care workers have been advanced with the ILO Domestic Workers’ Convention, governments are increasingly adopting 'cash for care’ schemes. These and other policies, combined with underfunding and poor regulation of care quality, further informalize or 'invisibilise ${ }^{66}$ paid care work and undermine existing protections of the formal employment relationship through shifts to agency work and so-called selfemployment. ${ }^{67}$

\section{Conclusion}

The Australian case study outlined in this chapter highlights both the resilience of the gendered division of labour in the domestic sphere, despite increasing female participation, and its continuing influence in shaping employment for workercarers in the market sphere. The gender norms reflected in the Harvester decision have changed to allow access to the market sphere for women, including women with care responsibilities.

In examining regulatory support for worker-carers, most scholarly focus has been on direct supports such as access to ‘family-friendly’ working time arrangements rather than the basic scaffolding of employment regulation that provides for the basis of the employment contract, pay, the regulation of working time and leave and opportunities for individual and collective voice. ${ }^{68}$ While this scaffolding is inadequate in both the National Employment Standards and in many femaledominated awards, it is important to acknowledge the role of the National Minimum Wage (NMW) in providing a higher 'floor' for low-paid women and worker-carers than in many other comparable OECD countries. Generally adjusted via annual wages reviews, the NMW is also an important pay benchmark in the PPL and DaPP schemes. 
The recognition of the domestic sphere in employment regulation has been partial and gendered. It has facilitated domestic violence leave and provided some accommodation of worker-carers. However, employment regulation has been largely unconcerned with the interconnection of market and domestic spheres, and has reflected, constituted and reinforced assumptions about the characteristics of ideal workers and the separation of work and care. ${ }^{69}$ Many worker-carer interventions such as carers leave and PPL may appear 'gender neutral', but provide in practice for the domestic responsibilities of women ${ }^{70}$ and do not change the ways in which work is organized, valued or remunerated. Thus, employment regulation often acts to reinforce and consolidate the gendered domestic and market division of labour.

Australia is not alone in this respect. Across the OECD, the growth of parttime work, concentrated amongst women, has failed to halt the growth of long hours worked by men, ${ }^{71}$ still structured around the ideal worker, unencumbered with caring responsibilities. As in other developed economies, many of the Australian regulatory interventions, including PPL, leave women responsible for managing work and care through participating in less regulated, part-time or other non-standard work that falls outside the SER. Consequently, women have limited access to good quality work in the market sphere or to more equal distributions of unpaid work and care in the domestic sphere. ${ }^{72}$ This is vividly illustrated in the social care sector, where a key issue is the inadequacy of the regulatory scaffolding in providing decent work, including for the many worker-carers employed in this sector. Regulatory gaps both reinforce the perception of social care work as low value work and underscore the limits of regulatory interventions to support worker-carers that are premised on the SER configuration. 
If we are to fundamentally transform the ways that domestic work and work in the market sphere is understood and undertaken and achieve greater gender equality in both spheres we need first to pay attention to the basic minimum labour standards available to men and women in the labour market. This includes the gendered impact of employment regulation on work and care through its shaping of classification structures, bargaining provisions and working-time arrangements. Second, we need to design new, integrated regulatory and policy interventions towards shared work and valued care that recognize worker-carers. This would mean both the sharing of unpaid care within the domestic sphere and recognizing the provision of social care as a shared responsibility between the state and households. ${ }^{73}$ In the market sphere this means reconfiguring employment regulation to ensure recognition, support and decent working conditions for working-carers - no matter who their employer or what their employment status. This is critical. As Rubery puts it: 'A set of policy levers is needed to start to reverse segmentation and destandardisation by increasing and spreading employer obligations to provide decent employment standards'. ${ }^{74}$

\section{References}

[ABS], Australian Bureau of Statistics. "Forms of Employment." In November 2013 Cat No 6359.0, 2014.

__—. "Gender Indicators, Australia, August 2015." In Cat No 4125, 2015. [ACTU], Australian Council of Trade Unions. "Outline of Claim: Family and Domestic Violence." 2014.

[QIRC], Queensland Industrial Relations Commission. "Queensland Services, Industrial Union of Employees V Queensland Chamber of Commerce and Industry Limited, Industrial Organisation of Employers and Others (a/2008/5) ". (2009).

Appelbaum, E., T. Bailey, and P Kalleberg Berg, A. L. "Shared Work, Valued Care: New Norms for Organizing Market Work and Unpaid Care Work." New York, NY: Alfred P. Sloan Foundation, 2002.

Armstrong, J, T Walby, P Berg, and A.L. Kalleberg. "The Gendered Division of Labour: How Can We Assess the Quality of Employment and Care Policy from a Gender Equality Perspective?". Benefits 17, no. 3 (2009): 263-75.

Baird, M, and G Whitehouse. "Paid Parental Leave: First Birthday Policy Review." Australian Bulletin of Labour 38, no. 3 (2012): 184. 
Baxter, J., and B. Hewitt. "Negotiating Domestic Labor: Women's Earnings and Housework Time in Australia." Feminist Economics 19, no. 1 (2013): 2953.

Baxter, J., and T.0. Tai. "Inequalities in Unpaid Work: A Cross-National Comparison." In Handbook on Well-Being of Working Women edited by Mary Connerley and Jiyun Wu, 653-71. Netherlands: Springer 2016.

Bosch, G. "Working Time and the Standard Employment Relationship." In Decent Working Time: New Trends, New Issues, edited by J-Y. Boulin, M. Lallement, J. Messenger and F. Michon, 41-64. Geneva: ILO, 2006.

Chapman, A. "Employment Entitlements to Carer's Leave: Domesticating Diverse Subjectivities." Griffith Law Review 18, no. 2 (2009): 453-74.

-_- . "Uncovering the Normative Family of Parental Leave: Harvester, Law and the Household." Hecate 33, no. 1 (2007): 28-42.

Charlesworth, S. "Law's Response to the Reconciliation of Work and Care: The Australian Case ". In Families, Care-Giving and Paid Work: Challenging Labour Law in the 21st Century edited by Grace James and Nicole Busby. UK: Edward Elgar, 2011.

Charlesworth, S, and I Campbell. "Right to Request Regulation: Two New Australian Models." Australian Journal of Labour Law 21, no. 2 (2008): 114.

Charlesworth, S, and A Heron. "New Australian Working Time Minimum Standards: Reproducing the Same Old Gendered Architecture?". Journal of Industrial Relations 54 (2012): 164-81.

Charlesworth, S, and F MacDonald. "Women, Work and Industrial Relations in 2014." Journal of Industrial Relations 57 (2015): 366-82.

Charlesworth, S, L Strazdins, L O'Brien, and S Sims. "Parents' Jobs in Australia: Work Hours Polarisation and the Consequences for Job Quality and Gender Equality." Australian Journal of Labour Economics 14, no. 1 (2011): 35.

Chesters, J, J. Baxter, and M Western. "Paid and Unpaid Work in Australian Households: Trends in the Gender Division of Labour, 1986-2005." Australian Journal of Labour Economics 12, no. 1 (2009): 89.

"Commonwealth Conciliation and Arbitration Court, Harvester Judgement (Ex Parte H V Mckay) 2 CAR 1." 1907.

Connell, R. "Gender and Power." Polity (1987).

Connell, R.W. "A Really Good Husband: Work/Life Balance, Gender Equity and Social Change." Australian Journal of Social Issues 40, no. 3 (2005): 369.

Craig, L. "Children and the Revolution a Time-Diary Analysis of the Impact of Motherhood on Daily Workload." Journal of Sociology 42, no. 2 (2006): 125-43.

England, P. "Emerging Theories of Care Work ". Annual review of sociology (2005): 381-99.

Folbre, N. "Reforming Care." Politics and Society 36, no. 3 (2008): 373-87.

Fredman, S, and J Fudge. "The Legal Construction of Personal Work Relations and Gender." Jerusalem Review of Legal Studies 1 (2013): 112-22.

Freedland, M, and N Kountouris. The Legal Constuction of Personal Work Relations. Oxford: Oxford University Press, 2011. 
Fudge, J. "Feminist Reflections on the Scope of Labour Law: Domestic Work, Social Reproduction and Jurisdiction." Feminist Legal Studies 22 (2014): $1-23$.

Hegewisch, A, and J.C. Gornick. "The Impact of Work-Family Policies on Women's Employment: A Review of Research from OECD Countries." Community, Work and Family 14, no. 2 (2011): 119-38.

Heron, A, and S Charlesworth. "Working Time and Managing Care under Labor: Whose Flexibility." Australian Bulletin of Labour 38, no. 3 (2012): 214.

Lewis, J, and S Giullari. "The Adult Worker Model Family, Gender Equality and Care: The Search for New Policy Principles and the Possibilities and Problems of a Capabilities Approach." Economy and society 34, no. 1 (2005): 76-104.

Loh, V, and H Kendig. "Productive Engagement across the Life Course: Paid Work and Beyond." Australian Journal of Social Issues 48, no. 1 (2013): 111-37.

MacDonald, F, and S Charlesworth. "Cash for Care under the NDIS: Shaping Care Workers' Working Conditions?". Journal of Industrial Relations (2016). . "Equal Pay under the Fair Work Act 2009 (Cth): Mainstreamed or Marginalised?". University of New South Wales Law Journal 36 (2013): 563-86.

Martin, B, M Baird, M Brady, B Broadway, B. Hewitt, G Kalb, L. Strazdins, et al. "Paid Parental Leave Evaluation: Final Report." Canberra Department of Social Services 2014.

Murray, J, and R Owens. "The Safety Net: Labour Standards in the New Era." In Fair Work: The New Workplace Laws and the Work Choices Legacy, edited by A Forsyth and A Stewart, 2009.

O'Connor, Julia, Ann Orloff, and Sheila Shaver. States, Markets, Families: Gender, Liberalism and Social Policy in Australia, Canada, Great Britain and the United States. Cambridge: Cambridge University Press, 1999.

OECD. "OECD Family Database: LMF2.2: The Distribution of Working Hours among Adults in Couple Families, ." www.oecd.org/social/family/database.

___. "Time Spent in Unpaid, Paid and Total Work, by Sex' OECD Gender Data Portal." 2015.

Palmer, E, and J Eveline. "Sustaining Low Pay in Aged Care Work." Gender, work \& organization 19, no. 3 (2012): 254-75.

Pocock, B. "Work/Care Regimes: Institutions, Culture and Behaviour and the Australian Case." Gender, work \& organization 12, no. 1 (2005): 32-49.

Pocock, B, and S Charlesworth. "Multilevel Work-Family Interventions Creating Good-Quality Employment over the Life Course." Work and Occupations (2015).

Pocock, B, S Charlesworth, and J Chapman. "Work-Family and Work-Life Pressures in Australia: Advancing Gender Equality in "Good Times"?". International Journal of Sociology and Social Policy 33, no. 9/10 (2013): 594-612.

Productivity Commission. "Workplace Relations Framework, Final Report." Canberra, 2015.

Rubery, J. "Regulating for Gender Equality: A Policy Framework to Support the Universal Caregiver Vision." Social Politics: International Studies in Gender, State \& Society, jxv036. (2015). 
Simonazzi, A. "Care Regimes and National Employment Models." Cambridge Journal of Economics 33, no. 2 (2009): 211-32.

Skinner, N., and B. Pocock. "The Persistent Challenge: Living, Working and Caring in Australia in 2014: The Australian Work and Life Index 2014." University of South Australia, Centre for Work and Life, 2014.

Smith, B. "Not the Baby and the Bathwater: Regulatory Reform for Equality Laws to Address Work-Family Conflict." Sydney Law Review 28, no. 4 (2006): 689-732.

Van Egmond, M, J Baxter, S Buchler, and M . Western. "A Stalled Revolution? Gender Role Attitudes in Australia, 1986-2005." Journal of Population Research 27, no. 3 (2010): 147-68.

Verloo, M, and E Lombardo. "Contested Gender Equality and Policy Variety in Europe: Introducing a Critical Frame Analysis Approach." In Multiple Meanings of Gender Equality. A Critical Frame Analysis of Gender Policies in Europe, edited by Mieke Verloo, 21-49: Central European University Press, 2007.

Vosko, L. "Precarious Part-Time Work in Australia and in Transnational Labour Regulation: The Gendered Limits of SER-Centrism." Labour \& Industry 17, no. 3 (2007): 45-70.

Walby, S. "Gender Mainstreaming: Productive Tensions in Theory and Practice." Social Politics: International Studies in Gender, State \& Society 12, no. 3 (2005): 321-43.

\section{Endnotes}

${ }^{1} \mathrm{~J}$ Armstrong et al., "The Gendered Division of Labour: How Can We Assess the Quality of Employment and Care Policy from a Gender Equality Perspective?," Benefits 17, no. 3 (2009).

${ }^{2}$ M Verloo and E Lombardo, "Contested Gender Equality and Policy Variety in Europe: Introducing a Critical Frame Analysis Approach," in Multiple Meanings of Gender Equality. A Critical Frame Analysis of Gender Policies in Europe, ed. Mieke Verloo (Central European University Press, 2007).

${ }^{3}$ Ibid., 28.

${ }^{4} \mathrm{~S}$ Walby, "Gender Mainstreaming: Productive Tensions in Theory and Practice," Social Politics: International Studies in Gender, State \& Society 12, no. 3 (2005).

${ }^{5}$ Ibid.

${ }^{6}$ Ibid.

${ }^{7}$ Ibid.; E. Appelbaum, T. Bailey, and P Kalleberg Berg, A. L., "Shared Work, Valued Care: New Norms for Organizing Market Work and Unpaid Care Work," (New York, NY: Alfred P. Sloan Foundation, 2002).

${ }^{8}$ R Connell, "Gender and Power," Polity (1987).

${ }^{9}$ B Pocock, "Work/Care Regimes: Institutions, Culture and Behaviour and the Australian Case," Gender, work \& organization 12, no. 1 (2005).

${ }^{10}$ Gottfried in this volume.

${ }^{11}$ M Freedland and N Kountouris, The Legal Constuction of Personal Work Relations (Oxford: Oxford University Press, 2011).

${ }^{12}$ S Fredman and J Fudge, "The Legal Construction of Personal Work Relations and Gender," Jerusalem Review of Legal Studies 1 (2013).; J Fudge, "Feminist 
Reflections on the Scope of Labour Law: Domestic Work, Social Reproduction and Jurisdiction," Feminist Legal Studies 22 (2014).

${ }^{13}$ G Bosch, "Working Time and the Standard Employment Relationship," in Decent Working Time: New Trends, New Issues, ed. J-Y. Boulin, et al. (Geneva: ILO, 2006).

14 J Lewis and S Giullari, "The Adult Worker Model Family, Gender Equality and Care: The Search for New Policy Principles and the Possibilities and Problems of a Capabilities Approach," Economy and society 34, no. 1 (2005).; Julia O'Connor, Ann Orloff, and Sheila Shaver, States, Markets, Families: Gender, Liberalism and Social Policy in Australia, Canada, Great Britain and the United States (Cambridge: Cambridge University Press, 1999).

${ }^{15}$ L Vosko, "Precarious Part-Time Work in Australia and in Transnational Labour Regulation: The Gendered Limits of SER-Centrism," Labour \& Industry 17, no. 3 (2007).

${ }^{16}$ Fudge, "Feminist Reflections on the Scope of Labour Law," 6, n12.

${ }^{17}$ Lewis and Giullari, "The Adult Worker Model Family, Gender Equality and Care.", n14; Appelbaum, Bailey, and Berg, "Shared Work, Valued Care.", n7; J Rubery, "Regulating for Gender Equality: A Policy Framework to Support the Universal Caregiver Vision," Social Politics: International Studies in Gender, State \& Society, jxv036. (2015).

${ }^{18}$ Bosch, "Working Time.", n13.

${ }^{19}$ M Van Egmond et al., "A Stalled Revolution? Gender Role Attitudes in Australia, 1986-2005," Journal of Population Research 27, no. 3 (2010).

${ }^{20}$ J. Baxter and T.O. Tai, "Inequalities in Unpaid Work: A Cross-National Comparison," in Handbook on Well-Being of Working Women ed. Mary Connerley and Jiyun Wu (Netherlands: Springer 2016).; A Hegewisch and J.C. Gornick, "The Impact of Work-Family Policies on Women's Employment: A Review of Research from OECD Countries," Community, Work and Family 14, no. 2 (2011).

${ }^{21}$ OECD, "Time Spent in Unpaid, Paid and Total Work, by Sex' OECD Gender Data Portal," (2015).

${ }^{22}$ Australian Bureau of Statistics [ABS], "Gender Indicators, Australia, August 2015," in Cat No 4125 (2015).

${ }^{23}$ V Loh and H Kendig, "Productive Engagement across the Life Course: Paid Work and Beyond," Australian Journal of Social Issues 48, no. 1 (2013): 123-24.

${ }^{24} \mathrm{~J}$ Chesters, J. Baxter, and M Western, "Paid and Unpaid Work in Australian Households: Trends in the Gender Division of Labour, 1986-2005," Australian Journal of Labour Economics 12, no. 1 (2009): 104.

${ }^{25}$ [ABS], "Gender Indicators, Australia, August 2015.", n22.

${ }^{26}$ N. Skinner and B. Pocock, "The Persistent Challenge: Living, Working and Caring in Australia in 2014: The Australian Work and Life Index 2014," (University of South Australia, Centre for Work and Life, 2014), 30.

${ }^{27}$ Ibid.

${ }^{28}$ OECD, "OECD Family Database: LMF2.2: The Distribution of Working Hours among Adults in Couple Families, ," (www.oecd.org/social/family/database).

${ }^{29}$ S Charlesworth et al., "Parents' Jobs in Australia: Work Hours Polarisation and the Consequences for Job Quality and Gender Equality," Australian Journal of Labour Economics 14, no. 1 (2011).

${ }^{30}$ Ibid.

${ }^{31}$ J. Baxter and B. Hewitt, "Negotiating Domestic Labor: Women's Earnings and Housework Time in Australia," Feminist Economics 19, no. 1 (2013): 49.

${ }^{32}$ Skinner and Pocock, "The Persistent Challenge," 20-21, n26. 
33 Ibid., 21.

${ }^{34}$ L Craig, "Children and the Revolution a Time-Diary Analysis of the Impact of Motherhood on Daily Workload," Journal of Sociology 42, no. 2 (2006).

${ }^{35}$ B Pocock and S Charlesworth, "Multilevel Work-Family Interventions Creating Good-Quality Employment over the Life Course," Work and Occupations (2015).

36 "Commonwealth Conciliation and Arbitration Court, Harvester Judgement (Ex Parte H V Mckay) 2 CAR 1," (1907).

${ }^{37}$ A Chapman, "Uncovering the Normative Family of Parental Leave: Harvester, Law and the Household," Hecate 33, no. 1 (2007).

38 The 'test case' was a uniquely Australian phenomenon in which the federal industrial relations commission, usually in response to an application from the Australian Council of Trade Unions (ACTU) - held public hearings to consider evidence for and against proposed changes in standard award conditions (Cooney et al., 2006). Where award conditions were modified, changes would typically flow on to all other industry awards.

${ }^{39}$ S Charlesworth, "Law’s Response to the Reconciliation of Work and Care: The Australian Case " in Families, Care-Giving and Paid Work: Challenging Labour Law in the 21st Century ed. Grace James and Nicole Busby (UK: Edward Elgar, 2011), 91. ${ }^{40} \mathrm{~J}$ Murray and R Owens, "The Safety Net: Labour Standards in the New Era," in Fair Work: The New Workplace Laws and the Work Choices Legacy, ed. A Forsyth and A Stewart (2009).

${ }^{41}$ Australian Bureau of Statistics [ABS], "Forms of Employment," in November 2013 Cat No 6359.0 (2014).

${ }^{42}$ S Charlesworth and A Heron, "New Australian Working Time Minimum Standards: Reproducing the Same Old Gendered Architecture?," Journal of Industrial Relations 54 (2012).

${ }^{43}$ A Chapman, "Employment Entitlements to Carer's Leave: Domesticating Diverse Subjectivities," Griffith Law Review 18, no. 2 (2009).

${ }^{44} \mathrm{~S}$ Charlesworth and I Campbell, "Right to Request Regulation: Two New Australian Models," Australian Journal of Labour Law 21, no. 2 (2008).

${ }^{45}$ Australian Council of Trade Unions [ACTU], "Outline of Claim: Family and Domestic Violence," (2014).

${ }^{46}$ Ibid.

${ }^{47}$ S Charlesworth and F Macdonald, "Women, Work and Industrial Relations in 2014," Journal of Industrial Relations 57 (2015).

${ }^{48}$ Productivity Commission, "Workplace Relations Framework, Final Report," (Canberra2015), 543-52.

${ }^{49}$ B Pocock, S Charlesworth, and J Chapman, "Work-Family and Work-Life Pressures in Australia: Advancing Gender Equality in "Good Times”?," International Journal of Sociology and Social Policy 33, no. 9/10 (2013): 601.

${ }^{50}$ Pocock and Charlesworth, "Multilevel Work-Family Interventions," 7, n35.

${ }^{51}$ Pocock, Charlesworth, and Chapman, "Work-Family and Work-Life Pressures in Australia," 599-600, n49.

${ }^{52}$ M Baird and G Whitehouse, "Paid Parental Leave: First Birthday Policy Review," Australian Bulletin of Labour 38, no. 3 (2012).

${ }^{53}$ Ibid.

${ }^{54}$ B Martin et al., "Paid Parental Leave Evaluation: Final Report," (Canberra

Department of Social Services 2014), 73.

${ }^{55}$ Ibid., 77-78.

${ }^{56}$ Ibid., 79. 
${ }^{57}$ Ibid., 81.

${ }^{58}$ Ibid., 11.

${ }^{59} \mathrm{P}$ England, "Emerging Theories of Care Work " Annual review of sociology

(2005).; N Folbre, "Reforming Care," Politics and Society 36, no. 3 (2008).; E Palmer and J Eveline, "Sustaining Low Pay in Aged Care Work," Gender, work \& organization 19, no. 3 (2012).

${ }^{60}$ Appelbaum, Bailey, and Berg, "Shared Work, Valued Care.", n7.

${ }^{61}$ A Simonazzi, "Care Regimes and National Employment Models," Cambridge Journal of Economics 33, no. 2 (2009).

62 England, "Emerging Theories of Care Work "., n59.

${ }^{63}$ Charlesworth and Heron, "New Australian Working Time Minimum Standards.", n42.

${ }^{64}$ F Macdonald and S Charlesworth, "Equal Pay under the Fair Work Act 2009 (Cth): Mainstreamed or Marginalised?," University of New South Wales Law Journal 36 (2013).

${ }^{65}$ Queensland Industrial Relations Commission [QIRC], "Queensland Services, Industrial Union of Employees V Queensland Chamber of Commerce and Industry Limited, Industrial Organisation of Employers and Others (a/2008/5)" (2009): para 4.8.

${ }^{66}$ See Delaney 2016 in this volume.

${ }^{67}$ F Macdonald and S Charlesworth, "Cash for Care under the NDIS: Shaping Care Workers' Working Conditions?," Journal of Industrial Relations (2016).

${ }^{68}$ A Heron and S Charlesworth, "Working Time and Managing Care under Labor: Whose Flexibility," Australian Bulletin of Labour 38, no. 3 (2012).; Pocock and Charlesworth, "Multilevel Work-Family Interventions."

${ }^{69}$ B Smith, "Not the Baby and the Bathwater: Regulatory Reform for Equality Laws to Address Work-Family Conflict," Sydney Law Review 28, no. 4 (2006): 701.

${ }^{70}$ R.W. Connell, "A Really Good Husband: Work/Life Balance, Gender Equity and Social Change," Australian Journal of Social Issues 40, no. 3 (2005): 375.

${ }^{71}$ Hegewisch and Gornick, "The Impact of Work-Family Policies on Women's Employment," 126, n20.

${ }^{72}$ Pocock, Charlesworth, and Chapman, "Work-Family and Work-Life Pressures in Australia," 608, n49.

${ }^{73}$ Appelbaum, Bailey, and Berg, "Shared Work, Valued Care,", n7.

${ }^{74}$ Rubery, "Regulating for Gender Equality," 22, n17. 